This is a post-print version of 'Morena Skalamera Groce (2018): Uncovering the Domestic Factor in the Sino-Russian Energy Partnership, Geopolitics,' published by Taylor \& Francis. DOI: 10.1080/14650045.2018.1511541

\title{
Uncovering the Domestic Factor in the Sino-Russian Energy Partnership
}

\author{
Morena Skalamera Groce
}

\begin{abstract}
What explains the differences in the Sino-Russian oil and gas cooperation? Overall, I suggest, the several trajectories are explained by the dissimilarities of oil and gas as commodities and potential foreign policy tools. These differences, along with other factors, such as corporate culture and individual personalities, shed light on the strategies of Russia's gas conglomerates, Gazprom and Rosneft. Yet, if a more nuanced understanding of variation within these energy markets illuminates the reasons behind the sequencing of oil and gas cross-border pipeline projects, what explains the particular timing of the landmark 2014 gas deal? Why after 15 years of stalemate in the Sino-Russian gas cooperation did breakthroughs occur in 2014? And what explains the modesty of the record in gas cooperation to date? Many factors are undoubtedly involved, both economic and political; however, I contend that the conclusive factor can be found in underlying domestic politics.

The article outlines the role of national narratives in driving both Russia and China's energy foreign policy and goes on to argue that the Sino-Russian gas breakthrough in 2014 was due to the peculiar way in which domestic factors paired with international circumstances to produce the outcome at that particular moment.
\end{abstract}

\section{Introduction}

There are a variety of domestic and external factors, as well as economic and geostrategic reasons that have boosted China-Russian energy cooperation in 2014. This fairly remarkable development, unimaginable only a short time ago, I contend, codifies shifting identity patterns in Eurasia. In terms of forging an energy partnership, China and Russia have long appeared to be a perfect match. However, it was only in 2014 that the China-Russia energy relationship reached the level of development that their geographical proximity and economic complementarity had long implied. As China's economy boomed, its demand for natural resources became a major factor in the regional and global economy.

Due to these commercial developments in place before the Ukraine crisis, Moscow's strategic posture had long stressed the need to "Look East." Russia's general turn to China had to do with Moscow's assessment that Asia, and China in particular, would be the major source of future economic growth. (Kokoshin 2011). Yet it was only in 2014 that Russia and China signed a megadeal in gas. In the aftermath of this deal, many scholars speculated whether a partnership which would transcend simple commerce would develop (Paik 2015; Røseth 2017). While the "energy alliance" designation (Wang 2016) hardly describes the character of Sino-Russian relations, the year 2014 certainly marked a historic moment in the two countries' cooperation in natural gas. To explain the raise of momentum leading to the 2014 breakthrough, this article argues that Sino-Russian energy interdependence is 
affected by the domestic context in which the economic relationship takes place, the energy companies in each country, and the personalities of crucial actors. The nexus between domestic conditions and foreign policy had been a major feature of the years leading to the historic 2014 gas deal. This very nexus was married to the personalities of leaders in power at that particular time. Individuals are key to decision-making in all regimes, authoritarian and democratic alike. The primacy of personalities in shaping and even upending policy outcomes is the most striking feature of present-day Russia and China (Lo 2015, 11; Easter 2008).

Moreover, in recent years, there has been much discussion of "narrative" as an essential prerequisite of a successful strategy, a storyline that not only provides a justification for particular actions but also creates expectations for the future and thusly helps others, friends as well as opponents, to adapt to a new situation (Freedman 2014, 30). To date, however, the ways that such "national narratives" have mediated the Sino-Russian energy relationship have not been addressed in necessary depth. Through an examination of Sino-Russian energy deals, this article promises to contribute to a discussion of these major themes: an illustration of the links between domestic political conditions and foreign policy; an explication that personalities matter both in foreign policy and corporate culture; and an examination of how energy companies drive outcomes in energy policy.

The article also provides an assessment of factors of change in global gas markets. The point at issue is a major redefinition of energy interdependencies: oil markets have long been international and gas markets are only just now becoming so. Some national oil companies (NOC) go international and rapidly adapt to the challenges of globalization (i.e. Rosneft), others struggle to do so. The growing globalization of gas trade, the strong rise in the use of renewables, and changes in modes of energy production and trade in the "shale revolution" age have caused spillovers into the realm of the RussiaChina energy partnership; this, in turn, enhances China's leverage in an already imbalanced bilateral relationship. These unexpected turns of events as seen from the perspective of Gazprom, strongly affected its market position in Europe. Among the unforeseen circumstances, the unconventional revolution has been the one that left Gazprom inevitably weakened and ultimately changed its strategic calculus in Eurasian gas geopolitics. ${ }^{1}$

The concluding section summarizes the results and follows with a discussion of the importance of these findings for both policymakers and future research.

\section{Oil and Gas as Explanatory Factors}

Sino-Russian gas cooperation differs in important ways from cooperation in oil. This has to do with the inherent differences between gas and oil as commodities and as potential foreign policy tools. Oil is difficult to produce but is a lucrative international business. Unlike oil, gas is comparatively easy to produce but difficult and expensive to transport. Considering that the value of what is being transported is much lower, the sunk costs of building gas pipelines are higher. In natural gas, Russia's eastern regions export infrastructure is still insufficient to make use of the country's hitherto largely underdeveloped resources (Gustafson 2012, 58; Itoh 2017). Moreover, gas pipelines, much more so than oil pipelines, create rigid relationships between suppliers and customers, making buyers potentially vulnerable to the geopolitical calculations of producers on the other end of the pipeline (Casier 2011, 542). Despite growing ties in gas markets, gas trade is still overwhelmingly regional and pipeline gas trade creates "umbilical cords" that are hard to break. Given the notorious history of distrust between Russia and China, many twists and turns intervened before the "Power of Siberia" gas pipeline actually turned out to be a viable option, while oil cooperation began earlier, in 2009. In light of important trustrelated setbacks in natural gas, rationalist approaches that seek to explain the Sino-Russian gas trade by focusing exclusively on interests (i.e. price disagreements) are incomplete and should be supplemented 
by normative factors (Ziegler 2013).

This article agrees with conventional wisdom, which states that the general trajectory of SinoRussian energy relations is well explained by an emphasis on firms' commercial interests. ${ }^{2}$ Oil is a more lucrative international business. And hence, unsurprisingly, there was more urgency in launching oil cooperation, which explains the sequencing of oil first and gas second in Sino-Russian energy projects. This, in turn, sheds light on the differing strategies of Gazprom and Rosneft in maximizing revenues and profits, both at home and overseas. Yet just as with oil trade, objective commercial interests had been pushing in the direction of gas cooperation since the early 1990s. A breakthrough, however, occurred only in 2014. While the differences in oil and gas can illuminate the reasons why oil cooperation - a lucrative international business - occurred first, this differentiation alone tells us nothing about why 2014 happened to be the year for a breakthrough in gas. This article argues that to understand the timing of the natural gas deal we have to look at other factors - namely changed incentives at the domestic level that affected the context of negotiation.

In the next sections, I provide evidence to illustrate that, when we turn our attention to the particular question of why now for the Sino-Russian 2014 gas deal, this article's approach adds more value to the discussion than theories concerned primarily with the maximization of wealth or power. Building on the insight that national identities bestow economic policy with social purpose, this article proposes a novel analytical framework. It emphasizes change in social priorities, and thus a novel construction of inter-subjective meanings as expressed in domestic political discourse and social mobilization occurring at that time period. The argument is cast in terms of energy companies' choices about their trade policy in the context of perceived interests, opportunities, incentives and constraints. The domestic-level concerns within which energy cooperation is, to borrow from Karl Polanyi, 'embedded' are remarkable, and their impact can cut both ways. They can push energy companies towards even closer cooperation or, at times, signal a departure from productive cooperation. This conceptual backdrop is important for the empirically grounded analysis of the nature of Gazprom and Rosneft, and the domestic landscape within which they operate.

\section{Gazprom vs. Rosneft}

Due to differing natures of the supply system and dissimilar structures of the two industries, the oil and gas sectors followed different trajectories in the modern economic history of Russia. The oil sector has been transformed into a more competitive segment of the economy after the crises of the 1990s. The outsized power that Rosneft enjoys in the present day derives from its acquisitions since the turn of the century, which, considering that the price of oil hovered at around $110 \$ /$ barrel, strongly boosted its dividends. Prices for crude oil are linked to international markets. As a truly privatized national oil company (NOC), Rosneft has been economically less beholden to the Russian government than Gazprom. ${ }^{3}$ Moreover, given that oil money strongly contributes to the state coffers, the power of Rosneft, and its CEO Igor Sechin, have soared.

The gas sector in Russia has had a completely different institutional trajectory. The government still maintains tight control over the gas business chain. Political control of exports remains important despite the lower profitability of gas as compared to oil. Acute politicization of the gas business remains a prominent feature of energy politics in Russia, in turn making Gazprom a very particular case of statemarket interaction (Belyi and Locatelli 2015). The political importance placed on Gazprom as the guarantor of gas to Russia's domestic market at regulated-below market prices, ${ }^{4}$ coupled with Gazprom's dependence on exports to a specific market, i.e. Europe, perpetuates politicization of the EU-Russia gas relations, something unheard of in EU-Russia oil trade. Oil companies in Russia are exempted from the role of a "policy tool" and therefore also free from allegations of using energy as a 
political "weapon."

This article's contention is that the different paths of Sino-Russian oil and gas trade cannot be understood without taking into account the incentives that Russian and Chinese state leaders have to engage in oil vs. gas cooperation, and the way that domestic corporate actors shape those incentives. The argument is rooted in the view that the most important factor to look at is the commercial interest of energy firms. Firm-to-firm relations, however, build on past interactions and on a variety of social, political, and institutional contexts that "contain" their negotiations at particular historical moments. Since the end of the Soviet Union, Russia's oil and gas sectors reflect opposing dynamics, the impact of which may drive a further reinforcement of the national oil giant, Rosneft, whereas it weakens the gas company Gazprom, both domestically and abroad. In gas, company-to-company interactions are rarely independent from the government (Belyi and Talus 2015). They are supported by the state especially for deals that carry geopolitical value along with economic relevance. In that sense, the Gazprom-CNPC landmark gas pipeline illustrates the extraordinary complexity of the international political economy (IPE) of natural gas.

Although the share of non-Gazprom gas production has been growing and independent companies such as Novatek play increasingly important roles in Russia, Gazprom remains an important tool of Russia's energy diplomacy. ${ }^{5}$ At the same time, the scale of innovation of energy markets does place new limits on energy firms" "state strategies." An important academic debate is taking place on the growing interdependencies and the parallel restriction of national policies not only in oil, but in gas policy, too. As a major source of government revenues, the energy sector plays a crucial role in Russia's economy. Strong dependence on exports makes Russia extremely vulnerable to strategic shocks such as the unconventional revolution and large oil price fluctuations. As recently as 2015, the oil and gas sectors accounted for $43 \%$ of the government budget and 53\% of total exports (Itoh 2017).

The preceding discussion has shown that, because of its inherent characteristics, oil creates interdependence but not vulnerability (Baldwin 1980; Keohane and Nye 1977 [2011]). ${ }^{6}$ This observation is at odds with the realist position in the literature on interdependence and conflict, which still sees oil as a strategic weapon used to exercise power (Krasner 1974; Hess 2003, 154; Glaser 2013). If in the past this was true for gas, it is basically no longer the case. This changing IPE of energy consists of actors at various levels (Belyi and Talus 2015, 3; Skalamera 2016). These include states, energy companies and supranational institutions, such as the EU.

The impact of unforeseen challenges in the energy landscape has its most evident manifestation in the ways energy firms react to them. Energy firms are thus the real drivers (or the lack of thereof) of Sino-Russian energy cooperation and, at the same time, the main actors coping with this increased asymmetry in an already unequal energy partnership. While an overly high decentralization of the oil sector stimulated a competitive centralization of Rosneft, an over-centralization of the Gazprom business led to its weakening (Belyi and Locatelli 2015). A second, related, point suggests that Gazprom and Rosneft have had varied degrees of success in their cooperation with China due to the inherent differences of oil and gas in shaping larger firm-to-firm interactions - and these companies' peculiar relationships with the state. Energy firms, indeed, do not operate in a vacuum. This article suggests that domestic events and, occasionally, a reformed sense of national purpose, (Laruelle 2008; Tsygankov 2016, 17) strongly affect corporate strategies.

The following case studies uncover the interplay of international influences and domestic circumstances in Sino-Russian energy trade. A focus on changing domestic narratives, in addition to prevailing economic factors illuminates the timing of the Sino-Russian 2014 gas breakthrough, which is difficult to explain from the standpoint of rationalist theoretical approaches. 


\section{Data and Method}

This article presents new results using primary data assembled through extensive interviews in the countries under examination. The analysis also draws on news reports and existing literature on the cases. Due to the nature of the question tackled and the available data, the case-study method was chosen to reveal how particular variables affect outcomes. ${ }^{7}$ While quantitative research can show correlation between a set of factors, it cannot say what causal role a particular factor played leading to a given outcome and with what degree of salience.

An in-depth case-study method is most useful when one has access to interviews with elites that reveal the inner decision-making process of the actors in question. Process tracing was used as an analytical tool to examine the case studies and establish the presence of different variables and the relationship between them. ${ }^{8}$ The choice of this method might lead to worries of selection bias and lack of generalizability ${ }^{9}$ - in that respect, empirical results across two robust case studies show that the salience of commercial interests of energy firms paired with individual personalities and historical domestic factors is paramount for energy policy change. Political history, institutional legacies, local cultures, worldviews, and other "structural" features account for a high degree of salience predicting either the onset or the nature of the outcome of broader energy trade deals. This data prompted a new line of reasoning and offered a way to link the emphasis, common to rationalist theories, on maximizing wealth or power (in Sino-Russian energy commerce) with identity politics' emphasis on furthering status or restoring dignity. Such an approach is better versed to explain massive yet unanticipated shifts in global politics.

There has been much scholarly work on the economic and strategic benefits of the recent SinoRussian energy deals. The case studies in this article, in covering two important developments of the Sino-Russian energy trade, suggest an alternative perspective highlighting the importance of commercial interests, which are imbued in historically specific domestic contexts. Consequently, when this article examines Sino-Russian energy interdependence it sheds light on a variety of national specificities pertaining to Russia and China and on the contestations occurring at the moment when the negotiation over these energy megadeals were taking place. The article seeks to further the debate on how domestic political dynamics interact with rationalist incentives to explain big shifts and occasionally surprising foreign policy outcomes. ${ }^{10}$ This approach goes beyond looking at ways in which domestic institutions aggregate (domestic and international) pressures, transforming them into state policy, which has been already widely researched by the liberal school. ${ }^{11}$

\section{Oil Cooperation - a Success Story}

Just as with Europe before, Russia's current economic "pivot" to China hinges primarily on cooperation in oil and natural gas. Out of the two - oil cooperation has been king. Chinese and Russian officials and oil companies have been discussing the construction of a cross-border oil pipeline since the mid-1990s. In the 1990s, when world oil prices were low and the Russian oil industry was starved for capital, Russia was interested in selling oil to China but the Chinese were in no hurry to finalize the negotiations. ${ }^{12}$ For all their protestations of amity, for most of this decade China and Russia remained noticeably distrustful of one another and placed a high premium on preservation of as much national sovereignty as possible. ${ }^{13}$

Nevertheless, Beijing's thirst for oil and its reliance on maritime transit for oil import made Russia's pipeline a very attractive alternative that could provide diversity both from the volatility of politics in the Middle East, and the risk of interruption of the shipping routes. ${ }^{14}$ Over the course of the 2000 s, Chinese strategists became acutely concerned about the security of oil transports as they travelled across 
the Indian Ocean and through the Strait of Malacca (Cohen and Kirshner 2012, 157). These analysts (Shi Hongtao 2004; Liu Xiaoli 2009) worried that the United States might impose a blockade in the event of a crisis. $^{15}$

The initial plan was for a pipeline from Angarsk in East Siberia to Daqing in north-eastern China but Moscow became increasingly concerned about building a pipeline to a single customer with strong monopsony power (i.e. China), and about the involvement of a private oil company-Yukos - in a deal of such a strategic significance. ${ }^{16}$ Rosneft, Russia's national oil company, which in the 1990s struggled to survive, swallowed Yukos's assets, and emerged as an increasingly powerful national oil champion (Poussenkova 2013). Along with Yukos's assets, Rosneft inherited the company's fascination with China. In light of this article's emphasis on personalities, Igor Sechin, one of the most influential persons in Putin's entourage, quickly positioned himself as a privileged interlocutor with the Chinese energy businesses. Nevertheless, protracted negotiations over pricing and disagreements over the route of the East Siberia-Pacific Ocean (ESPO) oil pipeline followed the initial accord in 2001. Then the 2008 global economic slump, the swelling debt of Russia energy companies, and declining Russian energy revenues due to the fall in the price of oil, once again created a gap between Russia's aspirations and achievements. $^{17}$

In 2009, Russia finally began work on a spur from Skovorodino to Daqing, China, in exchange for Chinese loans to two Russian oil companies, Rosneft and Transneft. The \$25 billion, twenty-year deal with Russia's Rosneft and Transneft would yield China 15 million tons of crude oil each year. It would also help with realizing one of Russia's most important geopolitical goals: increasing production of oil for sale in Asian markets. Under the Putin regime, this became the centrepiece of the Kremlin's approach to developing Siberia and the Far East. Expanded oil production in the Far East became critical not only for the development of the region, but also for Russia's ability to expand its economic and political weight in Asia. The Russian Far East is a gigantic and resource rich area, but is also thinly populated and remote from Russia's centres of power. It has lost a quarter of its population since the collapse of the centralized Soviet economy and is now home to only about six million people. ${ }^{18}$ It is therefore a case in point of how historically and socially specific domestic contexts play important roles in defining broader commercial interests (Welch Larson and Shevchenko 2010; Kirshner 2015).

Since then, oil cooperation has continued to grow in scale and profits, on pace with China's insatiable growth and Russia's interest in ensuring reliable supplies. ${ }^{19}$ Under Sechin's watch, Rosneft was quickly promoted to the preeminent spot in the domestic oil industry. The preceding contingent generalizations about oil as a more profitable and, thus, a more "sought after" commodity than gas held in the long term. However, there remains an irreducible element of choice and agency to explain how Sechin, President Putin's long-time associate, and his ostensible close personal relations with Chinese counterparts, might have helped forge the Sino-Russian oil partnership. ${ }^{20}$ Corporate decisions rarely, if ever, reflect "objective" commercial interests, but are made by individuals both conditioned and driven by their own particular cultural references, vested interests, biases, and the peculiarities of the business they run (Lo 2015, 5; Abdelal 2015). In early 2013, Rosneft acquired TNK-BP in a $\$ 55$ billion deal, which added about 9 million tons of oil to the company's production output and made Sechin the CEO of the world's largest listed crude oil producer. ${ }^{21}$ In June 2013, Rosneft and CNPC inked a deal reportedly worth $\$ 270$ billion over 25 years, with China putting itself on track to become Russia's largest client of oil. In January 2014 Transneft opened its second and final branch of the ESPO pipeline, just in time to double its capacity from 30 million tons a year to 50 million tons, for a total supply $365 \mathrm{~m}$ tonnes of oil to China over 25 years, in exchange for an additional prepayment of $\$ 30$ billion to Rosneft. ${ }^{22}$

While personal ties may have given Russia-China oil cooperation greater significance, geopolitical predicaments such as the Ukraine crisis, naturally, have taken a toll on the relationship. In late 2014 the plummeting value of the ruble, record levels of capital flight, and rising inflation were a direct 
consequence of external factors, above all the fall in global oil prices and the severely restricted access of Russian enterprises to Western credit finance (Abdelal, Skalamera and Atnashev 2016; Lo 2015). In the post-Ukraine world, Russia has hoped to garner China's support and counted on Chinese credit as it was compelled to reduce its exposure to Western financial markets. Moscow's expectations remained largely unmet. In the aftermath of the Ukraine crisis, Beijing had been leery of investing in Russia's upstream energy sector. ${ }^{23}$ There was no fundamental reason for a Chinese private-sector rush to Russia, unless Russia had sold itself so cheaply that it would had become irresistible for Chinese companies and asset managers. They knew, however, that as long as current conditions persisted, Russia's appetite for hard cash would certainly grow, and that Chinese companies would be able to buy assets at much cheaper prices. ${ }^{24}$

Igor Sechin's skillful manoeuvring with Chinese partners in the past has translated into the company extracting tens of billions from CNPC to pay off debts. Amid frustration over the post-Ukraine slow progress with equity deals, Sechin successfully used Indian partners as a counterbalance to irritate CNPC - in 2016, Rosneft sold a 15\% stake of Vankorneft, a Rosneft subsidiary, to ONGC, an Indian company (Henderson and Mitrova 2016). It seemed that the move had worked well to stunt momentum in deepening oil trade between China and Russia. After the Indian deal, China's Beijing Gas Group bought 20 per cent of a Russian equity field run by Rosneft for

$\$ 1.1 \mathrm{bn}$, in a deal that also gives the Russian oil conglomerate access to the Chinese domestic gas market. $^{25}$

Energy interdependence between China and Russia makes energy companies (i.e. Rosneft) into a particular influential interest group that almost invariably wants smooth trade and is averse to conflict (Abdelal 2015, 7; Kirshner, 2007). From Russia's perspective, the fallout with the West accelerated a turn to the east but it has also made such a move harder to accomplish. After all, amidst the current order China has benefited more than anyone, and there had been no reason to seek substantial adjustments. In fact, in light of Russia's weakness and China's own economic slowdown, ${ }^{26}$ CNPC's continued urgency to deepen corporate ties with Rosneft deserves attention.

An emphasis on a rationalist interest-based argument, which at the same time ignores intimate ties at the firm-to-firm level, has a difficult time explaining China's behaviour. In light of the Ukraine crisis, China has been understandably reluctant to wade into Russia's financial markets and, in turn, jeopardize its relationship with the West. ${ }^{27}$ Nevertheless, its continued commitment to Rosneft means that CNPC is concerned with protecting its high-profile corporate link to Sechin's firm. ${ }^{28}$ In September 2017, the energy bond between Russia and China was once again deepened by Rosneft. After a protracted lack of concrete deals CEFC China Energy spent $\$ 9.1$ bn for a 14.16 per cent stake in Rosneft. At the signing ceremony, Igor Sechin said he was "happy that it was specifically a Chinese corporation" that had bought a stake. ${ }^{29}$ The deal will give CEFC access to oilfields in eastern Russia close to the Chinese border and is the first time a Chinese company has taken a stake in one of the most important businesses controlled by the Kremlin. Some commentators argue that while in the past it has been much more difficult to invest in those of Russia's oil fields considered to be of "strategic importance," Russia's current desperate need for foreign investments catalysed the agreement and, ultimately, signalled Rosneft's vigorous "turn to the East." ${ }^{30}$ Be that as it may, the historically specific social context (i.e. Sechin's firm-to-firm intimate connection with the Chinese), certainly defined the bargaining and played a great role in propelling both sides towards the agreement. China's resourcefulness, displayed in its ability to reform old practices in order to take advantage of the situation, has been matched by the notable display of agility on Russia's part in adapting to the disagreeable, but fiscally indispensable, new rapport de forces. Such personal relationships are, however, almost completely absent from the scholarly literature on comparative and international political economy. We lack integrated understandings of both (material) international influences and normative aspects that might explain the contours of processes of foreign policy formation and change, and the ways energy firms interact to 
produce such mixed outcomes. Personal corporate relationships, once kindled, are difficult to undo. One of the central factors that has propelled the Sino-Russian partnership in oil is the enthusiasm that Rosneft's Sechin has put into cultivating personal relationships with major energy players in China.

According to Gabuev (2016), after the Ukraine crisis China's corporate players were encouraged to actively seek new opportunities in Russia but to avoid overtly exploiting Russia's difficult situation or seeking one-sided deals at knockdown prices. The leadership in Beijing worried that oversized appetites and the aggressiveness of Chinese investors would contribute to undesirable tensions and eventually encourage Russia to make a U-turn to mend relations with the West, which is why Xi personally blessed the giant Power of Siberia gas pipeline and intended it as a gesture of goodwill to the Kremlin. This instance highlights the nexus of foreign (energy) policy and domestic politics in Eurasia, and shows how economic developments not only shape but also are shaped by domestic concerns, such as history, identity, culture, and events. The eagerness of Sechin to forge close ties with Chinese corporate partners or the personal chemistry between Putin and Xi are factors that matter. IPE approaches focusing purely on firms' profit, however, often black box important agents and such path-dependent practices (Sharples 2016 , 4). In this sense, material facts are important, but national identities, and the historical memories embedded in them, give meaning to material facts so that energy companies can interpret and react to them (Abdelal 2001, 38). It is in this context that Sino-Russian oil trade has significantly deepened in recent years, whereas gas cooperation is just now slowly emerging. It is to this cooperation that I now turn.

\section{Gas Cooperation and the Uneasy Birth of the Power of Siberia}

After more than a decade of haggling, on 21 May 2014, China and Russia signed a historic agreement for China to import natural gas from Russia's Gazprom. The agreement, signed during a state visit by President Vladimir Putin in Beijing, consisted of a 30-year, $\$ 400$ billion gas deal for the delivery of 38 billion cubic meters of natural gas to China beginning in 2018.

The decades-long insufficient political will toward cooperation in gas on both Gazprom's and CNPC's side was by no means an accident. As shown above, Sino-Russian oil interdependence has continued to deepen and was bound to come about in the natural gas sector, too. Russia knew that the centre of gravity in the global energy market had shifted to Asia, predominantly led by surging demand from China and India. China, in particular, represented an enormous and fast expanding gas market. ${ }^{31}$ By contrast, energy demand in Europe, traditionally the main destination for Russia's exports, was projected to decrease. ${ }^{32}$

However, there were several reasons for the delay in gas cooperation: for one, price differences that pushed back the gas deal a full decade. Historically, CNPC has insisted that Gazprom sell natural gas to China at a price that is competitive with China's low domestic coal prices, while Gazprom wanted $\mathrm{CNPC}$ to pay natural gas prices that are tied to oil prices, like its customers in Europe do. ${ }^{33}$ Another question at issue was the preferred route: Gazprom wanted to ship gas from existing gas fields in Western Siberia to China's restive Xinjiang region; China long insisted that it needed energy in the populous coastal provinces of the east. With Moscow reluctant to accept China's terms, little real progress has been made on adding the gas element to the landmark deals in oil. One driver of Russia's stumbling pattern had been a domestic political dilemma: on the one hand there was resistance to "putting all Russia's eggs in the Chinese basket," 34 especially in terms of the strategic importance of natural gas as a preeminent Russian foreign policy tool. On the other, there were increasing domestic demands that Russia open up to China to invigorate economic growth. Worries about "strategic independence" in Asia prevailed and made Gazprom wait too long, only to realize in 2014, in extremis, that the longer it waited the worse deal it was ultimately going to receive. Gazprom, the dominant player 
in this process, has never been a strong proponent of increased ties with China along the lines of Rosneft's model of oil cooperation. It has, instead, ensured that any decisions concerning expansion to the east would be made with an eye to the geopolitical implications for Gazprom's business in Europe. ${ }^{35}$ Whereas Rosneft's Sechin, who had the prescience to see the coming shift to Asia, is considered a savvy business-man and even as a primary defender of Russia's new raison d'état, Gazprom's Miller had been slow to take advantage of this shift and his reputation has not been similarly enhanced. Easy money in Europe made Gazprom rich and slow to reform. This fixation with Europe has led some experts argue that Gazprom had been a liability for Russia's gas pivot to China. ${ }^{36}$ Even though China and Russia featured prominently in each other's energy trade diversification strategies, their conflicting perspectives in gas pointed to a more general problem of mistrust.

This article argues that the landmark gas deal happened thanks to an evolution in individual corporate actors' attitudes and national narratives at the domestic level, paired with a changed international context, a development that has been largely overlooked by the dominant rationalist theoretical approaches. The domestic context here coexists with the erratic impact of "strategic shocks." Gazprom's being torn between a new export strategy towards the Asian-Pacific and a focus on Europe demonstrates both the strength of path-dependent practices and of unexpected external shocks in the gas business. Short of being compelled by its own devastating "existential crisis" following the shale gas revolution it is very unlikely that Gazprom would have decided to vigorously "pivot" East and ink the landmark deal, at this particular moment.

Gas, as I noted, is more "risky" than oil and more difficult to replenish in response to arbitrary interruptions of supply, such as those that occurred in the winters of 2006 and 2009 as a result of disputes between Moscow and Kyiv (Kropatcheva 2011, 559; Stulberg 2015). This explains why there were so many twist and turns before gas cooperation finally became a viable option for China. ${ }^{37} \mathrm{But}$ were the differences in oil and gas - and the differences in their prices - as central to determining the course of political developments that ultimately led to the gas breakthrough in 2014?

The surveyed evidence is consistent with the claim that such differences explain the sequencing of Sino-Russian joint energy projects. Arguments that may seem foolproof, nevertheless, deserve scrutiny. Are these differences sufficient to account for the particular timing of the gas deal? The answer, it seems: only in part. In fact, there were other, additional powerful drivers in place to bridge the price gap. The big shift came as a fortuitous conjunction of two parallel circumstances: in 2013 Russia's long-standing business model in Europe started to crumble, and at that precise time, China, under the effect of disruptive air pollution, needed additional gas as a greener fossil fuel. In this instance, the inherent differences in oil and gas had only a minor influence on the choice of the particular time when the deal was clinched.

In the case of Russia, developments in Europe had a major bearing on its "security of demand." Long before events in Ukraine, Russia's slumping economic fortunes in Europe were induced by a trio of developments in Brussels: an emphasis on renewables and energy efficiency; efforts to reduce European energy dependence on Russia through diversification (Romanova 2016, 10); and a prolonged economic recession that pushed demand down (Schmidt-Felzmann 2011). It was mainly the EU's antitrust cases against Gazprom married to European attempts to wean itself off fuel supplies from Russia that filled Gazprom with indignation, ${ }^{38}$ and so, inaugurated its new preferred narrative: the Power of Siberia pipeline demonstrates Russia's ability to develop new export markets outside of Europe and is just the start of a key strategic bond between Russia and China, evocative of the gas-forpipes agreement with West Germany (Trenin 2015). The more difficult task had been ensuring broad backing of this new national narrative about "who Russia is in opposition to the West" by elites across the ideological spectrum. Moscow now insisted on its own distinctive civilization (rejecting the "universal values" of the West), a civilization that is shared through "Eurasia" and that with China has in common a distant Mongol legacy (Weigandt and Katzenstein 2017). Arrangements for gas trade 
directed exclusively westward were thus unmade by politics in 2013-2014 and rendered illegitimate by a transformation in political discourse at the domestic level. ${ }^{39}$ The West took actions that indicated indifference to Russia's status concerns (Krickovic and Weber 2016). This contributed to an altered perception of the West and strengthened the influence of the Eurasianists in the Russian political establishment (Tsygankov 2007, 381; Szostek 2017). Recent research into Russian foreign policy has noted the increasing importance placed on traditional values, prestige, and status, in which position and reputation form a critical component of diplomacy (Lo 2015; Mankoff 2015).

Faltering gas interdependence with Europe went hand-in-hand with a rehashed domestic political landscape, thereby empowering those segments of society whose interests were served by a hawkish, anti-Western policy that "looked East." Russia's "Eurasianist" ${ }^{40}$ politicians now had a pretext to include the "China card" in their domestic political thinking. Unsurprisingly, the "turn to the East" (povorot na Vostok) greatly intensified in 2014, in the aftermath of the Ukraine crisis and deteriorating relations with the West. These agents' (Eurasianists) new interpretation of the preexistent material incentives amid no change in Russia's economic capabilities, moderated the future course of action. Gazprom's commercial interests, when outfitted with a narrative intended to coincide with the evolving national discourse of Putin's Russia, produced a consequential geopolitical shift, the 2014 gas deal with China.

Changes in EU-Russia firm-to-firm relations - certainly a compelling social, not natural, construct - have powerfully influenced Gazprom's reevaluation of its business opportunities with China. Amid all this, Russia's economic capabilities did not improve. The country's economic decline continued and there was hardly any material basis for developing a more assertive foreign policy vis-à-vis the West. What changed, however, were Russian elites' choices based on subjective interpretations of vulnerability vis-à-vis the West that affected self-interested behaviour in the East. Big shifts occur when the domestic (i.e. national preference) context for foreign policy is fundamentally altered. It is within the parameters of such a system that Gazprom's much delayed "turn to the East" happened.

At the same time, Beijing gradually shifted towards a more proactive stance concerning gas cooperation with Russia due to its own domestic environmental concerns, consistent with the overarching attempt to position itself as a "responsible ecologic power" (Skalamera 2016). China was far too dependent on burning dirty coal, and it needed to incorporate much cleaner natural gas to alleviate already alarming environmental problems. ${ }^{41} \mathrm{~A}$ final component of China's opening to Russia was due to the security of trade routes. As Beijing's share of imported, sea lanes-reliant gas soared, growing concerns about transportation security arose from the geography of the Strait of Malacca, a narrow waterway surrounded by Singapore, Malaysia, and Indonesia (America's closest Asian allies), controlled by the US Navy and plagued by piracy. In the early 2010s, Obama's policy of rebalancing to Asia, which China perceived as a broad-based effort to contain Beijing in the Asian-Pacific (Blanchard and Flint 2017, 234), only strengthened China's concerns about reliance on these Straits (Shambaugh 2013, 289). Around the time of the Sino-Russian bargaining in gas, discussion of these issues in the context of China's threats to domestic stability increased their importance (Fravel 2012, 206).

This article argues that China's behaviour is due to a distinctive transformation in the policy discourse at a domestic level. It is unwise to assume that the geopolitical concern over the "Malacca Dilemma" by itself adequately explains the timing of China's turn to Russia. This concern has existed for some time but was now being renegotiated by a changed circumstance: Xi's agency and the act of "opening to Russia." "42 Altered circumstances within China - the gradual ideational orientation towards greener sources of energy and a heightened perception of the "Malacca Dilemma" have been the preeminent driver. Russia began to be regarded as a privileged partner in solving both headaches. In that sense, the argument fuses the liberal insight, which finds that commercial ties can give actors a large material incentive to forge cooperation, with the constructivist insight that there is a national preference affecting economic (i.e. energy) choices based on subjective interpretations of vulnerability 
(i.e. the Malacca Dilemma).

The crucial question is not to establish whether in China price-based (commercial) considerations prevailed over identity-driven considerations or, alternately, whether domestic identities and norms prevailed over putatively material interests. In providing evidence for the argument that national narratives shape how political actors define their interests, this article presents a more convincing explanation for the timing of big shifts in foreign policy, such as the Sino-Russian gas breakthrough. In China, just like in Russia, one set of social constructions replaced the other. The imperative of economic growth was being complemented by concern for the environment, ${ }^{43}$ which was gaining ground as a large social issue. ${ }^{44}$ The 2014 landmark gas deal is, thus, due to a deep transformation in the national identities of both countries on the eve of the Sino-Russian gas deal, which affected the foreign policy decisions they made. None of this was inevitable or inexorable. In fact, we would know relatively little if we only considered the purely systemic forces of this transformation.

Meanwhile, shifts in policy practices do not stem only from changes in national narratives, but are buffeted by unforeseen events at critical moments, such as the year 2014. First, the economic crisis in Europe and the EU's serious move towards renewables meant that Gazprom's traditional and most lucrative market was slipping away. Second, the impact of the U.S. shale gas revolution, leading to a supply glut in the international LNG market. Third, new natural gas infrastructure such as interconnectors, better storage facilities and new LNG import terminals have made the global gas market more interconnected and, as for Europeans, potentially less dependent on Russian gas supplies. These crises pushed Gazprom to pivot to China but those very woes in Europe were making it harder for Russia to conclude new accords with China on anything approaching favourable terms. Beijing knew that it could drive hard bargains with a Russia desperate for cash, credit, and new markets. During the years when Gazprom haggled CNPC financed and built a 30-bcm pipeline from Central Asia to service its Western provinces, ${ }^{45}$ it constructed a handful of LNG terminals and was also contemplating the development of its own shale gas reserves, which, on paper, are among the world's largest (Wilhelmsen and Flikke 2011, 890). CNPC, in other words had already contracted sufficient gas imports to successfully diversify its supply needs and was in no particular hurry to purchase piped gas from Russia. It would have done so if Russia was willing to sell itself cheaply, or, under extraordinary circumstances, to show a degree of political goodwill for a "friend" in need. The May 2014 outcome was the Power of Siberia pipeline and the concurrent circumstance was Russia's annexation of Crimea.

\section{The Situation after Ukraine}

Having established a gas relationship with China in the aftermath of the Ukraine crisis is perceived as a major success by Moscow. Some commentators argue that Gazprom had to settle for a lower price than it had hoped, but it still managed to strike the deal before the oil price, to which the gas price is tied, collapsed (Trenin 2015, 7; Gabuev 2016). Other analysts have put an emphasis on how the deal is far from being commercial from Moscow's perspective and simply amounts to a disastrous moneylosing project. ${ }^{46} \mathrm{~A}$ third group of commentators noted that it was the profit made by some insiders close to the Kremlin that was most consequential. Some individuals did benefit, so the deal was "commercial" for several well-placed insiders (Gabuev 2016; Zaslavskiy 2014).

The pertinent question here is not whether Russia got a good deal, given that Russia most certainly had to sell itself cheap. While this article recognizes the overriding importance of the firms' profit considerations, it seeks to draw attention to domestic factors such as identity and internal social contestations in energy trade negotiation. A company's conduct of international trade reflects profit considerations that are, however, embedded in corporate culture and a domestic systems of values. The material interests leading to the May 2014 deal, the most important of which is the agreement on the 
final price, do not, by themselves, explain why the time was ripe at that moment. This paper argues that the logic of energy interdependence (between the EU-Russia, and also, Russia-China) makes energy companies a particular influential group. Yet salient unit-level factors that operate largely in combination with economic forces both propel, and occasionally hinder the main actors (i.e. firms) and their supporters (i.e. national governments) from cooperation. In this view, what matters is how identities and norms influence the ways in which actors define their interests in the first place (Abdelal 2001, 19).

Favourable economic conditions for the May gas predated the Ukraine crisis. However, this geopolitical development boosted Russia's turn East and signalled a willingness to accommodate Beijing's priorities in a more substantial way. Then another unexpected shock, the fall in world oil prices starting in June 2014, turned the tables even more in China's favour. This last shock has been the most devastating for Moscow as of yet. The reasons why may be driven by the changing preferences of consumers worldwide, who tend to favour "green" energy, and technological innovations that are bringing the price of renewables down. Even after OPEC's frantic supply cuts in the spring of 2017, these cuts have not been enough to re-absorb the world's excess supply and oil prices are not likely to rebound to previous levels. Energy transition and climate change policies worldwide may therefore have serious geopolitical effects on the Sino-Russian energy relationship. ${ }^{47}$ All this is very bad news for Russia; a future rise in world oil prices would, ideally, shift the balance of power from China to Russia. It is during seller's market periods that producers (i.e. Russia) take advantage of consumers (i.e. China) to extract maximum price premium. ${ }^{48}$ Yet China's surging leverage might be even superior in future gas negotiations due to multiple options. Whereas Russia would never be able to formulate a gas export policy that does not include China as the biggest market in Asia, China would have no problem satisfying its growing gas demand without any supply from Russia, at least until around 2030 (Itoh 2017). Since the start of the Ukraine crisis Russia's economic and diplomatic position has taken a turn for the worse. It must sort out an economy that has become overly dependent on commodities and now has an overstretched military sector. ${ }^{49}$ The oil price is unlikely to recover to the level that Russia once considered essential for its economy. And for the time being, not only does Beijing consider Russia to be a particularly risky country in which to invest ${ }^{50}$ but it is not preoccupied with securing gas supplies from Russia's Eastern regions because of plentiful alternatives and the awareness that Russian gas in the East is reliant on the vast Chinese market.

Several years of recession, alienation from Europe, open antagonism with the United States, and few options available except a turn to the East has made concluding the energy partnership a higher priority for Moscow than it will ever be for China. If economic influences were acting alone, Moscow's diplomatic effort would naturally be focused on persuading the EU to restore economic relations. Yet, due to Russia's distinctive value-system and its aspirations of again being treated as a great power (Smith 2016), Moscow has displayed prideful resistance.

\section{Conclusion}

During the Victory Day celebrations in Moscow on 9 May 2015, Chinese troops marched across Red Square, a compelling sign of the depth and breadth of the Sino-Russian partnership. The nexus of economics, security, and subjective interpretations of self-interested behaviour in Sino-Russian energy relations, however, demands greater attention by students of IPE. This article constitutes a modest step in that direction. It sheds light on the evolving character of a relationship whose significance for area specialists, energy scholars, and students of international political economy has grown dramatically over the past ten years.

It adds to ongoing theoretical debates in IPE by identifying new causal pathways through which 
changing domestic narratives can influence the goals and content of a state's strategy. Additional research on this issue is sorely needed and should help identify the boundaries and limits of rationalist claims. To use Abdelal's convincing formulation $(2009,72)$, in contrast to rationalist approaches to IPE, which tend to assume that market participants, policy markets, and even whole societies unproblematically recognize the material incentives around them and act accordingly, this article argues that none of this is inevitable or inexorable. Recent work on how identity concerns affect the IPE of Eurasian energy relations may prove useful in this regards (Belyi and Talus 2015; Shaw 2012).

Gas is being increasingly depoliticized and turned into a globally traded commodity and is concurrently shifting to a system of floating prices and spot deals. Several implications relevant for the evolving character of Sino-Russian energy relations follow from these arguments: over the past decade, gas trade has transcended regional borders and gas market regulations have followed in lockstep. However, regional and national specificities are still very important features and illustrate the variety of reactions to the globalization of gas markets. As the different commercial experiences of Rosneft and Gazprom towards China indicate, economic complementarity (present both in oil and gas) cannot explain the different trajectories of Sino-Russian oil and gas cooperation. Individual personalities (such as that of Igor Sechin), histories, memories, biases, and prejudices that firms and individuals bring to the negotiating table do matter. So does the restraining role played by public policy (i.e. the European Commission), thus highlighting the growing limitations of the use of gas as a diplomatic tool. The strategic importance of commodities varies from nation to nation and over time.

During the past decade, a burgeoning empirical literature has emerged on the Sino-Russian energy relationship. However, existing studies still tend to focus on whether the Sino-Russian deals are commercially sound and just how uneconomical they might be for Russia. But this prevailing wisdom tell us nothing about why deals happen at particular time periods in the first place. The answer to why now for the 2014 gas deal, I propose, lies in the focus on domestic national preference formation. For Russia it was about perceptions of an increasingly grim EU-Russian gas trade in the face of regulations penalizing Gazprom's operations in Europe and a landmark antitrust investigation by authorities in Brussels. It was the open conflict with Europe, which has battered corporate earnings and national coffers, that acted as a significant step towards shelving disputes and pursuing Sino-Russian gas trade. The shift was legitimated by a changing narrative in the Kremlin; the rise of Eurasianists and their civilizational push to the East. Although Putin's approach today is definitely closest to realist thinking, it is hard to apply realism for explaining Russia's shift. Realists expect that policy change follow evolution in a state's relative economic capabilities. Yet in 2014 Russia's capabilities did not improve. A nationalist coalition coalesced around a domestic discourse perceiving the West as seeking to internally weaken Russia and attempting to limit Moscow's influence in the former Soviet region. This change in domestic thinking resulted in a more aggressive domestic narrative and signalled a major shift in foreign policy. For China, too, greater emphasis on identity-based politics, such as its tailoring an "environmentally responsible power" image as well as its heightened perception of the "Malacca Dilemma" - provide better answers for why reconciling differences with Russia was seen as vital at that precise moment. This study contends that whether and when economic interdependence promotes (or inhibits) cooperation across borders depends on the interaction among material influences, domestic narratives, and the subjective interpretations of self-interested behaviour among key actors. The core finding is notable because while domestic coalitions have been shown to influence domestic and national economic policy, their ability to directly shape foreign economic cooperation has been much less clear. In summary, this study advances the literature on domestic and national identity explanations for foreign economic policy. 
1. Against the backdrop of the U.S. shale revolution (i.e. the spreading of fracking technology), perhaps the most significant of the described shocks, the supply-demand balance of global oil and gas markets has significantly loosened. For a detailed analysis see Yergin (2014).

2. For detailed accounts on the influence of firms on states and, especially, the firms' subtle reshaping of domestic coalitions and national policy preferences, see Hirschman (1945[1980]); Lindblom (1977) and Culpepper (2011).

3. Even though the share of state ownership in Gazprom is lesser than one of Rosneft. Moreover, political interlinks between the Kremlin and Rosneft are even more significant than in Gazprom's case.

4. As observed by Marcel Salikhov, a Russian energy analyst, Gazprom has always branded itself as a 'socially responsible organization' accountable for Russian gas supplies. However, as Salikhov notes, it is questionable whether this extra 'responsibility' justifies state's subsidies in favor of Gazprom. Interview with the author, September 2015, Moscow.

5. Rosneft has often accused Gazprom of blocking access to networks. In 2013, following a request from Rosneft, the Russian ministry proposed a revision of Gazprom's export monopoly on LNG. Although this might appear as a significant step in the gradual liberalization of the Russian gas industry, the authorization is given directly to only two companies (Novatek, for the Yamal LNG project; and Rosneft). In the words of Marcel Salikhov, Russian energy analyst, discussing Russia's domestic gas market and Gazprom's pipeline export monopoly: "Russia's Domestic market is evolving but the competitive structure of the market is still distorted and is dominated by a few players." Interview with the author, September 2015.

6. The key difference between sensitivity and vulnerability interdependence hinges on the costs that countries would bear should relations between them be disrupted. States trading heavily that can easily locate close substitutes for the goods being exchanged clearly are interdependent but not vulnerable. At the same time, states conducting little trade that would have great difficulty locating substitutes for the goods being exchanged may be highly vulnerable. For a detailed analysis see Keohane and Nye's seminal study Power and Interdependence, 1977, [2011] pp. 10-16, (IV edition).

7. See George and Bennett (2005).

8. In process-tracing these events, I apply Bennett and Checkel's principles. See Bennett and Checkel (2014).

9. These are problems that often seem to confine qualitative researchers when they try to show the value of their craft relative to quantitative methods.

10. For more on constructivist approaches in IPE that emphasize that policy practices may result from political institutions, international norms and national identities, see Finnemore (1996); Wendt (1996) and Thomas Risse (2002).

11. Moravcsik (2008). See also Ikenberry (2011).

12. Especially in the late 1990s, when oil prices fell below $\$ 11$. See Erica, S. Downs 'SinoRussian Energy Relations: An Uncertain Courtship,' Brookings Report, 23 August 2010.

13. The Sino-Soviet split, which came to an end in 1991 with the self-liquidation of the USSR, prevented the two Communist giants from cooperating for almost thirty years (Hopf 2009). Historical memory - fraught with bitterness and mutual suspicion - remained engraved in their psyche and played a crucial role in the two countries' foreign-policy thinking. It also mitigated against fast recovery in economic relations. For a detailed account on how for 
decades the Sino-Russian strategic relationship was ridden with angst, see also Kuchins (2002) and Garnett (2000).

14. In the words of Tian Chunsheng, scholar at the Chinese Academy of Social Sciences, "The Middle East is not a stable place. Therefore, this unstable area can't provide the large requirement of oil and gas for resource stability in China." Interview with the author, 29 July 2013.

15. Concerns about transportation security arose from the geography of the Strait of Malacca, a six-hundred-mile-long waterway among Singapore, Malaysia, and Indonesia that is only one and a half miles wide at its narrowest point. Some 80 per cent of Chinese oil imports transit those Straits. Interview with Liu Xiaoli, Energy Research Institute (ERI) within the National Development and Reform Commission, China 19 July 2013.

16. In 2002, Mikhail Khodorkovsky's Yukos held talks about engaging the Chinese in the development of Eastern Siberian upstream, and building an oil pipeline that would service the Chinese market from those fields. Such a proposition, however, ran against Putin's plans to build a pipeline all the way to the Pacific port of Nakhodka, thereby adding an extra 3000 $\mathrm{km}$ to the original Khodorkovsky plan. In 2004, Khodorkovsky was arrested and accused by the Russian government of, among other things, large tax evasion. The Yukos Affair marked the beginning of a large renationalization of Russia's oil and gas industry. For a detailed discussion, see Gustafson (2012).

17. According to Leonid Grigoriev, a Russian energy analyst, "Moscow's dependence on revenue from energy exports, its determination to compensate for the plunge in global demand that began in 2008, and need for capital to tap new oil fields, ensured a more accommodating stance toward China." In conversation with the author, May 2014, Moscow.

18. The population of the Russian Far East faces a China that is becoming more powerful and beset by a growing population and potential pressure on arable land (Menon 1997).

19. Some notable developments: In June 2015 Russia surpassed Saudi Arabia to become China's top crude supplier (Bloomberg 2015). In March 2016, moreover, China overtook Germany as Russia's top crude consumer. (RT 2016).

20. Interview with Konstantin Simonov, President of Russia's National Energy Security Foundation. On the contours of the Sino-Russian May deal: "Maybe part of the Chinese philosophy was to wait. There were talks about taking shares in the Russian upstream business - Putin usually refused to do it - Sechin lobbied heavily to involve the Chinese in joint ventures. Gazprom may do the same in the Kovykta field. In the future CNPC may also acquire shares of Rosneft. For Sechin is comfortable to work with the Chinese. So CNPC could buy shares of Rosneft - maybe even better than granting equity shares in Chayanda and Kovykta." 30 May 2014, Moscow.

21. Six months later, Russian oil output then the largest in the world reached its post-Soviet record of more than 520 million tons of crude.

22. According to a Chinese industry insider, this is the second prepayment (agreed in March 2013, upon Xi's visit to Moscow), after the \$25billion-worth loan of 2009. See also: "Russia and China agree \$270bn oil deal" Financial Times, 21 June 2013.

23. In the words of Dr. Feng Yujun, Head of Russian studies at the China Institute of Contemporary International Relations: "The Western sanctions put a question mark over a smooth implementation of the existing agreements. We are not only talking about the gas deal, but the promised increases in oil, Yamal LNG, and the Tianjin refinery. The deterioration of the overall investment environment in Russia means that there is a lot of uncertainty surrounding these deals." Interview with the author, 11 September 2014.

24. Author's interview with Guan Guihai, Chinese Scholar, February 2015, Cambridge, MA. 
25. Foy, H. "Chinese gas company buys $20 \%$ of Russian field from Rosneft for $\$ 1.1 \mathrm{bn}$," Financial Times, 29 June 2017.

26. With slowing economic growth hitting its stock market, China had to deal with its own credit crunch. See for instance, "Putin's China Energy Deals May Hide Paper Tigers as Growth Slows", Bloomberg Business, 4 September 2015.

27. Despite Moscow's outreach, Chinese entrepreneurs have been wary about investing in Russia because closer ties with Russian companies might harm their economic links with the Unites States, a "global" partner where Russian ties are viewed as regional. Bloomberg Business "China Wary of Closer Russia Energy Ties, Ex-Cnooc Economist Says, 2 July 2015.

28. See for instance, "Rosneft deal boosts Russia-China relationship," Financial Times, 20 November 2017.

29. "Russia and China quietly build business bonds", Financial Times, 24 September 2017. See also "China Deepens Oil Ties with Russia in \$9 Billion Rosneft Deal," Bloomberg, 8 September 2017.

30. Phone Interview with a Chinese oil executive, 17 October 2017.

31. Sergey Karaganov, interview with the author, Moscow, August 2013; Andrey Kokoshin, interview with the author, Moscow, May 2014.

32. Interview with Tatiana Mitrova, Head of the Energy Institute of the Russian Academy of Sciences, 27 May 2014; The International Energy Agency estimates that Asia's natural gas use will increase by a factor of more than 2.6 by 2035 (and that China's will quadruple), while demand in Russia's traditional European markets will grow only slightly. The EU's natural gas demand is expected to peak at 473 billion cubic meters (bcm) in 2025-30 and thereafter decrease to $452 \mathrm{bcm}$ in 2040 .

33. Due to the Chinese still strongly regulated (and subsidized) domestic gas market, China was not prepared to pay the gas price that some European countries are paying to Gazprom. Liu Xiaoli, Chinese official, in conversation with the author, Beijing, July 2013. Zha Daojiong, a Chinese energy expert, in conversation with the author, Beijing, August 2013.

34. Sergey Karaganov, Interview with the author, Moscow, August 2013.

35. Sergey Komlev from Gazprom Export, in conversation with the author, August 2013, Moscow.

36. "Frankly speaking, Gazprom is a liability for Putin's pivot-to-Asia policy," said Keun Wook Paik, an expert on Sino-Russian energy cooperation at the Oxford Institute for Energy Studies. Quoted in Johnson, K. Russia's Stumbling Pivot to Asia, 8 May 2015, Foreign Policy.

37. Xiandeng Yi, Chinese diplomat, in conversation with the author, Beijing, August 2013.

38. By middle 2013 following the disappointments of the EU's Third Energy Package, with its rules on the "unbundling" of gas supply and distribution, and measures that promoted competition, Gazprom finally began to "pivot" East. Elena Burmistrova, Head of Gazprom export, in conversation with the author, June 2016, Moscow.

39. Despite these changes, Europe remains an essential market where Gazprom has maintained its market share, and, in 2016, Gazprom's gas supplies to Europe and Turkey reached an alltime record. At the same time, the European market has become increasingly "liquid" and interconnected. As a result, the prices at which Gazprom maintains its market share have gone down or, in other words, the Russian company gained market share by playing by the EU's gas market rules. About Gazprom - Marketing in Europe: http://www.gazprom.com/about/marketing/europe/; See also: $\mathrm{http}: / / \mathrm{www}$.gazpromexport.ru/en/statistics/ and FT, Gazprom targets increased gas sales in 
Europe, 27 April 2017.

40. For a more detailed discussion, see for instance Gil Rozman (2014, December), The Russian Pivot to Asia", The Asan Forum.

41. In the words of Jia Qingguo, Chinese scholar, "In the old days, pollution has always been secondary to economic growth, now the environmental factor is becoming a larger social concern, especially in the last few years." In conversation with the author, August 2013, Beijing.

42. Xi Jinping, for instance, is a strong supporter of the Paris Climate Agreement. See The Guardian 'China's Xi Jinping says Paris climate deal must not be allowed to fail', 19 January 2017. See also The Economist 'The rise and rise of Xi Jinping-Xi who must be obeyed', 20 September 2014; BBC News, Follow the Leader: Xi Jinping vs Deng Xiaoping, 25 October 2017.

43. National "12th Five-Year Plan" for Environmental Protection. Available at: http://english.mep.gov.cn/Resources/Plans/National_Fiveyear_Plan/201606/P020160601356 854927248.pdf., Accessed on 26 November 2017.

44. Zha Daojiong, Chinese scholar, Interview with the author, August 2013.

45. The delays over the gas deal were instrumental in pushing Beijing to turn to Central Asia, where, in 2007 it quickly negotiated and implemented long-term agreements with Turkmenistan, Kazakhstan, and Uzbekistan. This, in turn, led to China becoming the principal economic player in Central Asia and an emerging strategic actor there. The $4,000 \mathrm{~km}$ pipeline became operational in 2009 and is to western China and transporting $30 \mathrm{bcm}$ a year over 30 years.

46. In the words of Valery Nesterov, Russian oil and gas analyst at Sberbank CIB, "Cost is difficult to control in frontier areas, like East Siberia. I predict cost overruns as compared to the initial estimates, so the rate of return of this pipeline will be low or even negative." Interview with the author, 30 May 2014. See, also Natural Gas Europe, "Mikhail Krutikhin: "It's all about Russia's Incompetence," 4 December 2014; or Noel, P. "The Power of Siberia natural-gas project: commercial or political?” IISS Comment, January 2017.

47. As O'Sullivan, Overland and Sandalow (2017) hypothesize in their new working paper, "The Geopolitics of Renewable Energy" for oil and gas producers, the decline in petroleum revenue could in principle, provide an impetus for political reform and economic diversification. However, it could also generate new sources of instability, such as income inequality and corruption that can fuel societal unrest, and as a result jeopardize growth and regime legitimacy.

48. In pipeline gas trade, the price of the natural gas is usually indexed to fuel oil. Yet as Maugeri argued, the supply of oil is bound to remain significantly greater than global demand due to the rationalization in the use of hydrocarbons and the discovery of new sources of fossil fuels around the world. Maugeri (2017).

49. According to IHS Jane's Defense Budgets Annual Report, in 2015 the Kremlin boosted its military spending by 21 percent to $\$ 54.1$ billion. IHS Jane Press Release," Growing Security Fears Boost Defense Budgets, IHS Says", 16 December 2015, http://press.ihs., Accessed in February 2016.

50. China has recently increased its influence over Russia by virtue of its strength and of Russia's economic woes. It has, for instance, taken a cautious approach in its opening to Russia in response to its own volatile stock market and Russia's increased "riskiness" due to its open conflict with the West. 


\section{Funding}

This work was supported by the Harvard Kennedy School's Geopolitics of Energy Project's Postdoctoral Fellowship; Belfer Center for Science and International Affairs, Harvard University [Postdoctoral Fellowship].

\section{References}

Abdelal, R. 2001. National purpose in the world economy. Ithaca: Cornell University Press. Abdelal, R. 2009. Constructivism as an approach to international political economy. In

Routledge Handbook of International Political Economy (IPE), ed. M. Blyth. Oxon, UK: Rutledge.

Abdelal, R. 2015. The multinational firm and geopolitics: Europe, Russian energy, and power.

Business and Politics 17(3):553-76. doi:10.1515/bap-2014-0044.

Abdelal, R., M. Skalamera, and M. Atnashev. 2016. Russia: Tribulations and Toska. Boston, MA: Harvard Business School Supplement 716-074.

Baldwin, D. A. 1980. Interdependence and power: A conceptual analysis. International Organization 34:471-506. doi:10.1017/S0020818300018828.

Belyi, A., and K. Talus. 2015. Introduction. In States and markets in hydrocarbon sectors, ed. A. Belyi and K. Talus. New York, NY: Palgrave.

Belyi, A., and C. Locatelli. 2015. State and markets in Russia's hydrocarbon sectors: Domestic specificities and interrelations with the West. In States and markets in hydrocarbon sectors, ed. A. V. Belyi and K. Talus. New York, NY: Palgrave.

Bennett, A., and J. Checkel. ed. 2014. Process tracing: from methodological roots to best practices. In Process tracing in the social sciences: From Metaphor to analytic tool, 1-37. Cambridge, UK: Cambridge University Press.

Blanchard, J. F., and C. Flint. 2017. The geopolitics of China's maritime silk road initiative. Geopolitics 22 (2):223-45. doi:10.1080/14650045.2017.1291503.

Casier, T. 2011. The rise of energy to the top of the EU-Russia Agenda: From interdependence to dependence? Geopolitics 16 (3):536-52. doi:10.1080/14650045.2011.520862.

Cohen, D., and J. Kirshner. 2012. The cult of energy insecurity and great power rivalry across the Pacific, Chapter 6. In The nexus of economics, security and international relations in East Asia, ed. A. Goldstein and E. Mansfield. Stanford, CA: Stanford University Press.

Culpepper, P. D. 2011. Quiet politics and business power: Corporate control in Europe and Japan. Cambridge, UK: Cambridge University Press.

Easter, G. M. 2008. The Russian state in the time of putin. Post-Soviet Affairs 24 (3):199-230. doi:10.2747/1060-586X.24.3.199.

Finnemore, M. 1996. National interests in international society. Ithaca: Cornell University Press. Fravel, M. T. 2012. Economic growth, regime insecurity, and military strategy: Explaining the rise of noncombat operations in China, Chapter 7. In The nexus of economics, security and international relations in East Asia, ed. A. Goldstein and E. Mansfield. Stanford, CA: Stanford University Press.

Freedman, L. 2014. Ukraine and the art of crisis management. Survival 56(3):7-42.

Gabuev, A. 2016. Friends with benefits? Russian-Chinese relations after the Ukraine Crisis. Moscow, Russia: Carnegie Moscow Center.

Garnett, S. W. 2000. Limited partnership. In Rapprochement or rivalry? Russia-China relations in a changing Asia, ed. S. W. Garnett. Washington, DC: Carnegie Endowment for International Peace.

George, A. L., and A. Bennett. 2005. Case studies and theory development in the social sciences. 
Cambridge, UK: MIT Press.

Glaser, C. 2013. How oil influences U.S. National Security. International Security 38 (2):112-46. doi:10.1162/ISEC_a_00137.

Gustafson, T. 2012. Wheel of fortune. Cambridge, UK: Harvard University Press.

Henderson, J., and T. Mitrova. 2016. Energy relations between Russia and China: Playing chess with the dragon. OIES Paper: WPM 67, Oxford Institute for Energy Studies, Oxford, UK.

Hess, G. 2003. Liberal hopes with no guarantees. In Economic interdependence and international conflict, ed. E. D. Mansfiled and B. M. Pollins. Ann Arbor, Michigan: University of Michigan Press.

Hirschman, A. O. 1945 [1980]. National power and the structure of foreign trade. Berkeley: University of California Press.

Hopf, T. 2009. Identity relations and the sino-soviet split. In Measuring identity - Guide for social scientists, ed. R. Abdelal and Y. M. Herrera, Chapter 10, 279-316. New York, NY: Cambridge University Press.

Ikenberry, G. J. 2011. Liberal leviathan: The origins, crisis, and transformation of the American World Order. Princeton: Princeton University Press.

Itoh, S. 2017. Sino-Russian energy relations in Northeast Asia and beyond: Oil, natural gas, and nuclear power in "Japan and the Sino-Russian Entente". NBR Special Report n. 64. The National Bureau of Asian Research, Seattle, Washington.

Keohane, R., and J. S. Nye. 1977 [2011]. Power and interdependence. London, UK: Longman.

Kirshner, J. 2007. Appeasing bankers: financial caution on the road to war. Princeton, NJ: Princeton University Press.

Kirshner, J. 2015. The economic Sins of modern IR theory and the classical realist alternative. World Politics 67 (1):155-83. doi:10.1017/S0043887114000318.

Kokoshin, A. 2011. Сценарии развития Восточной Сибири и российского Дальнего Востока, [Scenarios for the development of East Siberia and the Russian Far East]. Moscow, Russia: URSS.

Krasner, S. 1974. Oil is the exception. Foreign Policy, No. 14. pp. 68-84 doi:10.2307/1147947.

Krickovic, A., and Y. Weber. 2016. To harass and wait out: Sources of American conduct towards Russia. Moscow, Russia: Russia in Global Affairs.

Kropatcheva, E. 2011. Playing both ends against the middle: Russia's geopolitical energy games with the EU and Ukraine. Geopolitics 16 (3):553-73. doi:10.1080/ 14650045.2011.520863.

Kuchins, A. C. 2002. Limits of the Sino-Russian strategic partnership. In Russia after the fall, ed. A. C. Kuchins, 217-19. Washington, DC: Carnegie Endowment for International Peace.

Laruelle, M. 2008. Russian eurasianism: An ideology of empire. Washington, DC: Woodrow Wilson Center Press.

Lindblom, C. E. 1977. Politics and markets: The world's political economic systems. New York, NY: Basic Books.

Lo, B. 2015. Russia and the new world disorder. Washington, DC: Brookings Institution Press. Mankoff, J. 2015. Russia's Asia Pivot: Confrontation or cooperation? Asia Policy 19:65-87. doi:10.1353/asp.2015.0009.

Maugeri, L. 2017. OPEC's misleading narrative about world oil supply. Harvard Kennedy School, Belfer Center for Science and International Affairs, Policy Brief.

Menon, R. 1997. The strategic convergence between Russia and China. Survival 39 (2):101-25. doi:10.1080/00396339708442914.

Moravcsik, A. 2008. The new liberalism. In The Oxford Handbook of International Relations, ed. C. Reus-Smit and D. Snidal. Oxford: Oxford University Press.

O'Sullivan, M., I. Overland, and D. Sandalow. 2017. The geopolitics of renewable energy. Belfer Center Working Paper, Harvard Kennedy School, Belfer Center for Science and International Affairs, Cambridge, MA. 
Paik, K. 2015. Sino-Russian gas and oil cooperation: Entering into a new era of strategic partnership? OIES Paper: WPM 59, Oxford Institute for Energy Studies, Oxford, UK. Poussenkova, N. 2013. Russia's Eastern energy policy: A Chinese puzzle for Rosneft. Paris,

France: IFRI, Russia/NIS Center.

Risse, T. 2002. Constructivism and international institutions: Toward conversations across paradigms. In Political science: The state of the discipline, ed. H. Milner and I. Katznelson, 597-623. New York, NY: Norton.

Romanova, T. 2016. Is Russian energy policy towards the EU only about geopolitics? The case of the third liberalization package. Geopolitics 21 (4):857-79. doi:10.1080/ 14650045.2016.1155049.

Røseth, T. 2017. Russia's energy relations with China: Passing the strategic threshold? Eurasian Geography and Economics. doi:10.1080/15387216.2017.1304229.

Schmidt-Felzmann, A. 2011. EU member states' energy relations with Russia: Conflicting approaches to securing natural gas supplies. Geopolitics 16 (3):574-99. doi:10.1080/ 14650045.2011.520864.

Shambaugh, D. 2013. China goes global: The partial power. New York, NY: Oxford University Press.

Sharples, J. D. 2016. The shifting geopolitics of Russia's natural gas exports and their impact on EURussia gas relations. Geopolitics 21 (4):880-912. doi:10.1080/14650045.2016.1148690.

Shaw, T. M. 2012. Conclusion: Energy governance, global development, and new research agendas. In Dynamics of energy governance in Europe and Russia, ed. C. Kuzemko, A. Belyi,

M. Keating, and A. Goldthau. Hampshire, UK: Palgrave.

Shi Hongtao. 2004. Zhongguo nengyuan anquan zaoyu 'Maliujia kunju" [China's energy security encounters the "Malacca Predicament"]. Zhongguo qingnian bao, June 15. Beijing, China.

Skalamera, M. 2016. Sino-Russian energy relations reversed: A new little brother. Energy Strategy Reviews 13-14:97-108. doi:10.1016/j.esr.2016.08.005.

Smith, H. 2016. Statecraft and post-imperial attractiveness: Eurasian integration and Russia as a great power. Problems of Post-Communism 63:171-82. doi:10.1080/10758216.2016.1145063.

Stulberg, A. N. 2015. Out of gas? Russia, Ukraine, Europe, and the changing geopolitics of natural gas. Problems of Post-Communism 62:2. doi:10.1080/10758216.2015.1010914.

Szostek, J. 2017. Defense and promotion of desired state identity in Russia's strategic narrative. Geopolitics 22 (3):571-93. doi:10.1080/14650045.2016.1214910.

Trenin, D. 2015. From Greater Europe to Greater Asia? The Sino-Russian Entente. Moscow: Carnegie Moscow Center.

Tsygankov, A. P. 2007. Finding a civilizational idea: "West," "Eurasia," and "Euro-East". Russia's Foreign Policy, Geopolitics 12 (3):375-99.

Tsygankov, A. P. 2016. Russia's foreign policy - Change and continuity in national identity. 4th ed. London, UK: Rowman and Littlefield.

Wang, T. 2016. The Great Russia-China oil alliance is here (And why it matters). Washington, DC: The National Interest.

Welch Larson, D., and A. Shevchenko. 2010. Status seekers. Chinese and Russian responses to U.S. primacy. International Security 34 (4):63-95. doi:10.1162/isec.2010.34.4.63. Wendt, A. 1996. Social theory of international politics. New York, NY: Columbia University Press.

Weygandt, N., and P. J. Katzenstein. 2017. Mapping Eurasia in an open world: how the insularity of Russia's Geopolitical and civilizational approaches limits its foreign policies. Perspectives on Politics 15:2. doi:10.1017/S153759271700010X.

Wilhelmsen, J., and G. Flikke. 2011. Chinese-Russian convergence and central Asia.

Geopolitics 16 (4):865-901. doi:10.1080/14650045.2010.505119.

Xiaoli, L., ed. 2009. "Jundui yingfu zhongda tufa shijian he weiji feizhangzheng junshi xingdong yanjiu" [A study of Nonwar military operations by the Armed forcees to deal with major sudden incidents or crises]. Beijing: Guofang daxue chubanshe. 
Yergin, D. 2014. The global impact of shale gas. Project Syndicate, Prague, the Czech Republic. January 08.

Zaslavskiy, I. 2014. Insiders benefit from Gazprom-CNPC gas deal, but Russia's budget loses. London: Chatham House.

Ziegler, C. E. 2013. Energy pipeline networks and trust: The European Union and Russia in comparative perspective. International Relations 27(1):3. doi:10.1177/0047117812460879 